\title{
NUTRITIONAL AND PHYSICO-CHEMICAL EVALUATIONS OF MORINGA OLEIFERA SEEDLINGS AND OIL
}

\author{
Siyanbola T.O. ${ }^{1 *}$, Edobor-Osoh A. ${ }^{2}$, Ajanaku C.O. ${ }^{3}$, Akinsiku A.A. ${ }^{4}$, Adedapo E.A. ${ }^{5}$, Aladesuyi O. ${ }^{6}$, Olanrewaju \\ I.O. ${ }^{7}$, Jokotagba O.A. ${ }^{8}$ \\ *1,2,3,4,5,6,7 Department of Chemistry, Covenant University, P.M.B. 1023, Ota, Ogun State, Nigeria \\ ${ }^{8}$ Department of Science Laboratory Technology, Abraham Adesanya Polytechnic, P.M.B. 1020, Ijebu-Igbo, Ogun State,
} Nigeria

*Corresponding Author: -

Email ID: tolu.siyanbola@covenantuniversity.edu.ng

\begin{abstract}
: -
This work was intended to respectively examine the proximate analysis; mineral compositions and physicochemical parameters of Moringa oleifera seeds and its extracted seed oil. Harvested seedlings of Moringa oleifera plant obtained from Chukwun community in Kaduna State of Nigeria presented an oil yield of 42.51\%. Percentage values of 3.47, 6.84, 3.99, 26.48, 48.29 and 12.44 respectively represents the moisture content, crude fibre content, total ash, protein content, crude fat content and carbohydrate content of the seeds. The mineral elemental concentration carried out showed potassium having the highest concentration of $368.95 \mathrm{mg} / \mathrm{kg}$ while zinc concentration was the lowest (6.82). Physicochemical examinations of its seed oil reveal $194.75 \mathrm{mg} \mathrm{KOH} / \mathrm{g}$ sample, $68.41 \mathrm{gICl} / 100 \mathrm{~g}$ sample, and $5.6 \mathrm{mg} \mathrm{KOH} / \mathrm{g}$ sample respective values for saponification, iodine and acid values. The findings from this investigation show that Moringa oleifera seed and oil extracted from it could be consumed and its oil could be used as base materials for several industrial processes.
\end{abstract}

Keyword: Chukun, Moringa oleifera, Crude fibre, Physico-chemical, Industrial, Mineral.

\section{(c) $(\$)$}




\section{INTRODUCTION}

Moringa oleifera is a popular domestic plant known for its versatile use in the area of food and medicine. It is native to Indian subcontinent and now domesticated in the tropics and subtropical areas of the world (Fozia et al. 2012). It is commonly called "benzoil tree", "drumstick tree" or "horse radish tree", "miracle tree" in English (USDA, 2014), "Okwe oyibo" in Igbo, "Zogeli" in Hausa and "Ewe igbale" in Yoruba speaking people of Nigeria (Anwar et al., 2007). Moringa oleifera belongs to the family Moringaceae comprising of about fourteen different species. The 5 to $10 \mathrm{~m}$ height tree can survive severe climatic conditions such as wide range of rainfall calculated at $250 \mathrm{~mm}$ and above $3000 \mathrm{~mm}$, pH 5.0 to 9.0 and in barren soil (Morton, 1991; Fozia et al. 2012). In the tropical and sub-tropical countries, the leaves, flowers, fruits and immature pods of the tree form part of orthodox diets. The leaves are extremely rich in Vitamin A, B and C, protein and essential minerals such as iron and calcium when compared with regular fruits such as oranges, bananas, spinach and milk (Dahot, 1988; Anhwange et al., 2004, Kamal, 2008). The medicinal potential cum antimicrobial activities of Moringa oleifera is tremendous. The root, leaf, bark, fruit, flowers, gum, seed and seed oil have been utilized for various ills in the autochthonous medicine (Odebiyi and Sofowora, 1999; Fozia et al. 2012). Aqueous extract of the plant have been found to possess inhibitory activity against micro-organisms including Escherichia coli, Staphylococcus aureus, Pseudomonas aeruginosa, Bacillus subtilis, Basidiobolus ranarums and Basidiobolus haptosporus (Nwosu and Okafor, 1995; Saadabi and Abu Zaid, 2011). The fatty acid profile of its seed oil allows for Moringa oleifera seed oil to be formulated into useful organic coatings (Siyanbola et al. 2015). The locals in the Northern states of Nigeria have shown a lot of interest in the cultivation and process of Moringa oleifera plant due to the numerous applications the plant provides. They use the seed flour as natural coagulant for their water treatment purposes. This study became imperative as these locals could hardly prepare anything without adding part(s) of this plant as supplement. Therefore, this work evaluates the proximate and mineral analyses of Moringa oleifera seed flour.

\section{Materials and Methods}

Moringa oleifera seeds were obtained from Chukwun in Kaduna State, Nigeria. The pods were air dried and de-hulled to obtain the seeds. Seed oil was extracted using the Soxhlet extractor with n-hexane as solvent for extraction. The moisture content of the defatted Moringa seeds was determined by heating $2.0 \mathrm{~g}$ of the sample in a crucible placed in an oven at $105{ }^{\circ} \mathrm{C}$ till a constant weight of the crucible was obtained. The ash content was determined by the incineration $1.5 \mathrm{~g}$ samples placed in a muffle furnace maintained at $550{ }^{\circ} \mathrm{C}$ for $3-4$ hours. The crude fibre content was determined by digestion of samples. The protein content was determined through the Kjeldah method (AOAC, 1990). The mineral analysis was carried out according to Novozamsky et al., 1983. The physico-chemical analyses such as iodine value, saponification value, peroxide value and acid value were all carried out on the seed oil using AOCS, 2003 and Hundiwale et al., 2009 methods.

\section{Results and Discussions}

Table 1 presents the result of proximate composition of Moringa oleifera seeds. The $3.47 \%$ moisture content of Moringa oleifera seed is by far less than that of African nutmeg (Monodora myristica) having 14.7\% moisture content (Dawodu, 2009). Kernels from both seeds are used as condiment for food spicing in Nigeria. The low moisture content is an indication that the seeds could be stored for longer period of time. The low ash content value of $3.99 \%$ is correspondent to some staples as being good source of minerals. The high protein content of $26.48 \%$ gives an indication of its relevance for human and animal consumption. This value is within the range of important legumes and high protein bearing animals (Bhuiyan et al; 1986). The fat content of the Moringa oleifera seed under study (48.29\%) is higher than that reported for melon seeds (17.36-25.06\%) by Ebuchi and Avwobobe (2006) but slightly above the 45.84\% reported by Abiodun et al. (2012) for Moringa oleifera seed, this difference may be due to variation of weather conditions and the species used for analysis.

Table 1: Proximate analysis of the Moringa oleifera seed (w/w \%)

Mean values \pm Standard deviation, $n=3$

\begin{tabular}{|l|l|}
\hline Constituents & Percentage $(w / w ~ \%)$ \\
\hline Moisture content & $3.47 \pm 0.06$ \\
\hline Crude fibre content & $6.84 \pm 0.42$ \\
\hline Total ash & $3.99 \pm 0.21$ \\
\hline Protein content & $26.48 \pm 0.84$ \\
\hline Crude Fat content & $48.29 \pm 0.68$ \\
\hline Carbohydrate content & $12.44 \pm 0.53$ \\
\hline
\end{tabular}

The mineral concentrations of the seeds investigated are presented in Table 2. From the results, the highest concentration of $368.95 \mathrm{mg} / \mathrm{kg}$ represents the mineral composition of potassium in the seed sample. The concentrations in $\mathrm{mg} / \mathrm{kg}$ for calcium, magnesium, sodium and iron were 215.68, 198.79, 129.34 and 125.72 respectively. The mineral concentration of iron from the sample under study is $400 \%$ higher than the value report by Abiodun et al. (2012). The differences observed may be ascribed to soil composition, analytical methods used as well as weather conditions of the area under study. The significant high concentration of potassium in the seed is responsible for the claimed treatment for blood pressure by its consumers. Potassium also assists in controlling kidney failure and respiratory defects. Potassium, calcium and magnesium are all regarded as macro-minerals. The high concentrations of calcium and magnesium in the sample will 
enhance quality bones and teeth, relaxation and contraction of muscles, blood clotting, blood pressure regulation, protein building and nerve transmission. The $125.72 \mathrm{mg} / \mathrm{kg}$ concentration level for iron (micro-mineral) place Moringa oleifera seed as a good source of iron mineral for metabolism, DNA synthesis, immune function, healing and anemia prevention. Primarily, it's essential presence in proteins, hemoglobin and myoglobin which channel oxygen through the muscles and blood assert the relevance of Moringa oleifera seed as a "Miracle seed" as it's been adjudged in some quarters Minerals such as cadmium, Nickel and lead were not detected in the sample under study.

Table 2: Mineral's composition of Moringa oleifera seed

\section{N.D: Not Detected}

\begin{tabular}{|l|l|}
\hline Mineral Elements & Concentration $(\mathbf{m g} / \mathbf{k g})$ \\
\hline Manganese & $8.36 \pm 0.25$ \\
\hline Zinc & $6.82 \pm 0.02$ \\
\hline Iron & $125.72 \pm 0.15$ \\
\hline Potassium & $368.95 \pm 0.21$ \\
\hline Magnesium & $198.79 \pm 0.48$ \\
\hline Calcium & $215.68 \pm 0.19$ \\
\hline Sodium & $129.34 \pm 0.42$ \\
\hline Cadmium & N.D \\
\hline Nickel & N.D \\
\hline Lead & N.D \\
\hline
\end{tabular}

The results presented for physico-chemical properties of Moringa oleifera seed oil (Table 3) were seen to have absolute dependence of the method of extraction and climatic conditions prior to the harvest of samples. Lalas and Tsaknis (2002) used cold pressure, $\mathrm{n}$-hexane and (1:1) chloroform methanol ratio in carrying out their extractions, their samples were harvested in India. The contrary is for the sample under investigation, which was harvested in Nigeria but $n$-hexane, was used for the extraction process. The values for refractive index, saponification value and iodine value are respectively $1.461 ; 194.75 \mathrm{mg} \mathrm{KOH} / \mathrm{g}$ sample and $68.41 \mathrm{gICl} / 100 \mathrm{~g}$ samples, these values respectively slightly differ from those obtained through cold pressure extraction by Lalas and Tsaknis (2002). The acid value (5.6 mg KOH/g sample) is lower than the maximum permitted for unrefined oil (FAO/WHO, 1993). This connotes that Moringa oleifera seed oil possess low rancidity degree.

Table 3: Physico-chemical properties of Moringa oleifera seed oil

\begin{tabular}{|l|l|}
\hline Parameters & Values \\
\hline $\begin{array}{l}\text { Refractive index } \\
\text { (at } 40^{\circ} \mathrm{C} \text { ) }\end{array}$ & 1.461 \\
\hline $\begin{array}{l}\text { Specific gravity } \\
\text { (at } 40^{\circ} \mathrm{C} \text { ) }\end{array}$ & 0.894 \\
\hline $\begin{array}{l}\text { Iodine value } \\
\text { (gICl/100g) }\end{array}$ & 68.41 \\
\hline $\begin{array}{l}\text { Saponification value } \\
\text { (mg KOH/g sample) }\end{array}$ & 194.75 \\
\hline $\begin{array}{l}\text { Acid value } \\
\text { (mg KOH/g sample) }\end{array}$ & 5.6 \\
\hline $\begin{array}{l}\text { Viscosity } \\
\text { (cSt at } 40^{\circ} \mathrm{C} \text { ) }\end{array}$ & 68 \\
\hline
\end{tabular}

\section{Conclusion}

The nutritional, mineral elemental composition and physico-chemical parameters of Moringa oleifera seed and oil have been studied. The nutritional aspect shows that the seed and oil from the plant could be consumed. Though the seed oil is non-drying oil (having acid value less than $130 \mathrm{mg} \mathrm{KOH} / \mathrm{g}$ sample) but through appropriate formulations it could also serve as a useful base material for industrial purposes. The seedlings are rich in mineral element contents hence, could be used to fortify food.

\section{References}

[1].Farooq F., Rai M., Tiwari A., Arif Khan A., Farooq S. (2012) Medicinal properties of Moringa oleifera: An overview of promising healer. Journal of Medicinal Plants Research, 6(27), 4368-4374.

[2].Anwar, F., Latif, S., Ashrat, M. and Gilani, A.H. (2007) A food plant with multiple medicinal uses. Phytotherapy Research, 21:17-25.

[3].United States Department of Agriculture. (2014) Agriculture Research Service, Germplasm Resources Information Network (GRIN): http://www.arsgrin.gov/cgi-bin/npgs/html/taxon.pl?24597.

[4].Morton J.F (1991). The horseradish tree, Moringa pterygosperma (Moringaceae)- A boon to arid lands? Econ. Bot. 45:318-333. 
[5].Dahot M.U. (1988) Vitamin contents of flowers and seeds of Moringa oleifera. Pakistan Journal of Biochemistry, 21: 21-24.

[6].Anhwange B.A., Ajibola V.O. Oniye S.J. (2004) Chemical studies of the seeds of Moringa oleifera (Lam) and Detarium microcarpum (Guill and Sperr). Journal of Biological Sciences, 4: 711-715.

[7].Kamal M. (2008) Moringa oleifera Lam - The miracle tree. http://www.pharmainfo.net/reviews/moringaoleifera-lam-miracle-tree

[8].Odebiyi A, Sofowora EA (1999) Pytochemical screenings of Nigerian medicinal plants part 11. Lyodia 44:234-246.

[9].Nwosu M.O., Okafor J.L. (1995) Preliminary studies of the antifungal activities of some medicinal plants against Basidiobolus and some other pathogenic fungi. Mycoses 38:191-195.

[10]. Saadabi A.M., Abu ZAI (2011) An in vitro antimicrobial activity of Moringa oleifera L. seed extracts against different groups of microorganisms. Asian Journal of Basic and Applied Sciences, 5:129-134.

[11]. Siyanbola T.O., James O.O., Gurunathan T., Sasidhar K., Ajanaku K.O., Ogunniran K.O., Adekoya J.A., Olasehinde G.I., Ajayi A.A., Olaofe O., Akintayo E.T., Raju K.V.S.N. (2015) Synthesis, characterization and antimicrobial evaluation of polyesteramide resin from moringa oleifera seed oil (moso) for surface coating application. Canadian Journal of Pure and Applied Sciences, 9(1): 32293240.

[12]. A.O.A.C. (1990) 15th Official methods of Analysis. Association of Official Analytical Chemists, Washington D.C. USA. Pp. 807-928.

[13]. Novozamsky I., Houba V.J.G., Van E.C.K., Van V.W. (1983) Plant nitrogen and phosphorus in plant tissue, novel digestion technique for multi-element. Plant analysis communication in soil science and plant analysis, 14: $239-248$.

[14]. Dawodu F.A. (2009) Physico-chemical studies on oil extraction processes from some Nigerian grown plant seeds. Electronic Journal of Environmental, Agricultural and Food Chemistry, 8(2): 102-110.

[15]. Bhuiyan A.K.M., Ratnayake W.M., Ackaman R.G. (1986) Stability of lipids and poly - unsaturated fatty acids during smoking of Atlantic mackerel (Scomber scombus). Journal of America Oil Chemistry Society, 63, 324-328.

[16]. Abiodun O.A., Adegbite J.A., Omolola A.O. (2012) Chemical and Physicochemical Properties of Moringa Flours and Oil. Global Journal of Science Frontier Research Biological Sciences, 12(5), 1218.

[17]. Lalas S., Tsaknis J. (2002) Characterization of Moringa oleifera Seed Oil Variety "Periyakulam 1". Journal of Food Composition and Analysis, 15: 65-77.

[18]. FAO/WWHO (1993) Fats, oils and related product. Food standard program. Codex Alimentarius Commission. Food and Agriculture Organization of the United Nations. World Health Organization, Rome. 8: 33-35. 